\title{
Tramas territoriais na comercialização de produtos agrícolas em territórios fronteiriços
}

\author{
Anderson Luís Espírito Santo \\ Universidade Federal de Mato Grosso do Sul, Brasil \\ anderson84luis@gmail.com
}

\section{Edgar Aparecido da Costa}

Universidade Federal de Mato Grosso do Sul, Brasil edgarac10@gmail.com

\section{Alejandro Gabriel Benedetti}

Universidade de Buenos Aires, Argentina

alejandrobenedetti@outlook.com

Cita sugerida: Espírito Santo, A. L., Costa, E. A. y Benedetti, A. G. (2018). Tramas territoriais na comercialização de produtos agrícolas em territórios fronteiriços. Mundo Agrario, 19(42), e097. https:// doi.org/10.24215/15155994e097

Recibido: 24 agosto 2017 - Aceptado: 11 julio 2018 - Publicado: 07 diciembre 2018

(c) (1)(2) Esta obra está bajo licencia Creative Commons Atribución-NoComercial-CompartirIgual 4.0 Internacional http://creativecommons.org/licenses/by-nc-sa/4.0/deed.es_AR 


\section{Tramas territoriais na comercialização de produtos agrícolas em territórios fronteiriços}

Trama territoriais na marketing of agricultural products in fronteiriços territórios

Anderson Luis Espirito Santo

Universidade Federal de Mato Grosso do Sul, Brasil

anderson84luis@gmail.com

Edgar Aparecido da Costa

Universidade Federal de Mato Grosso do Sul, Brasil

edgarac10@gmail.com

Alejandro Gabriel Benedetti

Universidade de Buenos Aires, Argentina, Argentina

alejandrobenedetti@outlook.com

\section{Resumo:}

O objetivo deste artigo é analisar as tramas territoriais na comercialização de produtos agrícolas nas feiras livres de CorumbáMS, na fronteira Brasil-Bolívia. As tramas são as relações de complementaridade e oposição entre os territórios. A partir de uma abordagem qualitativa pela finalidade exploratória e descritiva reconheceu-se a importância de se estudar o desenvolvimento territorial rural e as fronteiras. Os feirantes bolivianos são maiorias nas feiras e a produção agrícola brasileira é insuficiente para abastecer o mercado local, o que justifica a entrada de alimentos a partir da Bolívia. As tramas se formam a partir das práticas dos atores que se complementam e se opõem nas relações diárias e nos jogos de poder sob o território.

Palavras-chaVe: Tramas Territoriais, Desenvolvimento Rural, Feira Livre, Território, Fronteira.

\section{Abstract:}

The objective of this article is to analyze the territorial schemes in the commercialization of agricultural products in the street markets of Corumbá-MS, in the border Brazil-Bolivia. The schemes are the relations of complementarity and opposition between the territories. From a qualitative approach for the exploratory and descriptive purpose it was recognized the importance of studying rural territorial development and borders. The Bolivian markets are major in the fairs and the Brazilian agricultural production is insufficient to supply the local market, which justifies the entry of food from Bolivia. The schemes are formed from the practices of the actors who complement each other and oppose each other in daily relationships and power plays under the territory.

KEYWORDS: Territorial schemes, Rural Development, Street markets, Territory, Frontier.

\section{INTRODUÇÃo}

Este trabalho objetiva analisar as tramas territoriais na comercialização de produtos agrícolas nas feiras livres de Corumbá-MS, na fronteira Brasil-Bolívia. As tramas territoriais são compreendidas aqui como as relações de complementaridade e oposição entre os territórios. Neste estudo, as tramas se materializam dentro das feiras livres da cidade de Corumbá, que está localizada na porção ocidental do Estado de Mato Grosso do Sul, na fronteira do Brasil com a Bolívia. Fundada em 21 de setembro de 1778, é uma das mais antigas do estado, possuindo contato territorial a Leste com Ladário-MS, no lado brasileiro, e com Arroyo Concepción (distrito de Puerto Quijarro, da província Germán Busch, departamento de Santa Cruz de La Sierra) a Oeste, no lado boliviano. 
A abordagem territorial vem sendo motivação de trabalho de diversos cientistas sociais que, nos últimos anos, dedicam-se a estudar o processo de formação e desenvolvimento do território e suas territorialidades. Contudo, estudar o território é algo complexo, daí a necessidade de delineá-lo e conduzi-lo a um determinado fim. Os territórios fronteiriços vislumbrados neste estudo são marcados por assimetrias socioeconômicas e intensas relações de trocas e fluidez das mobilidades humanas e passagens pela fronteira(Costa, 2011). $\mathrm{Na}$ fronteira são compartilhados, guardadas as racionalidades individuais, diversos espaços de manifestações coletivas. Num desses casos, as feiras livres de Corumbá, são verdadeiros pontos de encontro da população fronteiriça. Majoritariamente dominada pelos bolivianos reflete o vívido territorial em suas múltiplas dimensões - cultural, política, econômica e social (Espírito Santo et al., 2017b).

Apesar da existência superior a meio século, a participação dos feirantes bolivianos nas feiras livres de Corumbá é discutida pelo poder público local, principalmente em razão da pressão dos comerciantes brasileiros. O comércio legal ou ilegal é um dos principais propósitos que incentiva as mobilidades existentes nas regiões fronteiriças (Benedetti, 2011). Para além da ilegalidade, temos que a comercialização de produtos da agricultura familiar sempre esteve presente no abastecimento parcial das áreas urbanas desse território fronteiriço, tanto do lado brasileiro quanto do lado boliviano. Para os camponeses, direta ou indiretamente, as feiras livres são o principal canal de venda de seus produtos (Espírito Santo, 2017a). Logo, a necessidade de se compreender a apropriação (uso) do território (formação das feiras) e as tramas territoriais dentro destas feiras, advindas das experiências e relações diárias entre brasileiros e bolivianos.

No caso das feiras livres localizadas numa das bandas de um território nacional na fronteira, considerando essa lógica, seu papel original frequentemente é adulterado. Originalmente, as feiras livres devem funcionar como um canal de venda no qual os produtores rurais viabilizam a comercialização de sua produção, o que de outra forma seria difícil nessa economia de pouca liquidez e concorrência, por vezes, desleal (Santos, 2009). Contudo, nas feiras de Corumbá vendem-se muito mais que produtos da agricultura familiar.

A ilegalidade, a necessidade ou a questão de indiferença são três temas diferentes e não mutuamente exclusivos que se fazem presentes, diariamente, nos territórios fronteiriços. A vida nas regiões fronteiriças possui uma dinâmica própria, que em muitos sentidos desafia a ordem nacional e seus mecanismos de controle e vigilância, transcendendo o dogma da soberania (Costa, 2013). Um exemplo é o caso da feira livre de Corumbá que, atualmente, é formada por quase $80 \%$ de bolivianos, além de ser um verdadeiro cenário de descontrole e ilegalidade (Espírito Santo, 2015).

Partindo do objetivo proposto, as questões norteadoras que motivam esta pesquisa são: como ocorre a comercialização de produtos agrícolas na fronteira Brasil-Bolívia? Como se dá a formação das tramas territoriais dentro das feiras livres? Quão intensamente ocorrem tramas sociais nas dobras do legal, ilegal, ou da necessidade dos atores? Para tanto foi concebido um referencial teórico (parte 3) que indica a importância de se estudar a abordagem territorial, com ênfase na discussão do território, das ruralidades e da fronteira. Além disso, este artigo apresenta uma seção para a estratégia de pesquisa adotada.

A seção dos resultados foi dividida em quatro partes. A primeira destinada à caracterização da feira livre. A segunda parte apresenta os resultados que destacam a convivência cultural fronteiriça existente nas feiras, seguida da terceira parte que retrata as tramas territoriais dos agricultores e vendedores de hortaliças nas feiras de Corumbá. Por fim, tem-se a quarta parte dos resultados que apresenta a legalidade e a necessidade neste território fronteiriço, no que tange a comercialização de produtos agrícolas. Posteriormente, apresentam-se as considerações finais e as referências bibliográficas.

\section{Estratégia de PesQuisa}

A produção do conhecimento científico vem sendo marcada por uma grande diversificação de temas, objetivos e resultados. Dessa forma, para atingir o objetivo proposto, este estudo foi construído a partir de uma abordagem qualitativa pela finalidade exploratória e descritiva. Utilizou-se como estratégia de 
investigação a pesquisa bibliográfica, com coleta de informações através de entrevistas semiestruturadas, documentação e pesquisa de campo.

A pesquisa exploratória foi realizada por meio da triangulação, que surge como uma "estratégia de pesquisa das ciências sociais respaldada na utilização de diversos métodos para investigar um fenômeno, possibilitando ao pesquisador a capacidade descrever e interpretar o mundo social através do seu ponto de vista" (Espírito Santo, 2018, p. 3). Assim articulou-se o uso de pesquisa bibliográfica (livros e artigos científicos, em sua grande maioria), com entrevistas e levantamento de documentação sobre as feiras (jornais antigos, atas, leis e decretos).

A pesquisa descritiva foi realizada por meio de um roteiro de entrevistas semiestruturado junto aos atores que formam e tem interesse na feira livre de Corumbá. Buscaram-se diferentes olhares sobre o mesmo tema. Para tanto a população da pesquisa foi formada por feirantes ( 92 entrevistas com feirantes brasileiros, 20 bolivianos), fiscais de postura do município (4 fiscais), 70 consumidores, associações (1 representante da Associação Comercial e Empresarial de Corumbá e 1 representante da Associação de Trabalhadores Autônomos das Feiras Livres de Corumbá e Ladário), e pelo poder público brasileiro (3 funcionários da Prefeitura Municipal de Corumbá, 1 do Ministério da Agricultura, Pecuária e Abastecimento - MAPA e 1 da Receita Federal).

As entrevistas ocorreram entre 14 de dezembro de 2014 e 22 de julho de 2015 , principalmente na feira livre (em sua maior parte) e nas associações e órgãos públicos supracitados, com liberdade para o entrevistado falar livremente, sendo as respostas imediatamente transpostas para folhas de anotação. Os depoimentos sobre assuntos específicos foram mantidos bem próximos da fala original, corrigindo apenas os tempos verbais e expressões equivocadas da língua portuguesa. Teve-se a preocupação de manter o sigilo dos entrevistados, de modo que serão representados, neste artigo, como E-1 (para o Entrevistado 1; E-2, E-3, e sucessivamente para os demais entrevistados).

\section{Abordagem terRitorial, DESENVOLVIMENTO RURAL E TRAMAS TERRITORIAIS}

A abordagem territorial é uma temática que vem sendo retomada, nas três últimas décadas, com intuito de se compreender o desenvolvimento do território e suas territorialidades. No interim desse avanço assistese o desenvolvimento de estudos que vêm sendo chamados de "a nova ruralidade" (Favareto, 2010), onde os pesquisadores apresentam que "não faz mais sentido tratar o rural como sinônimo do agrário (...) é preciso compreendê-lo, sobretudo, por sua natureza eminentemente territorial” (Favareto, 2010, p. 299). Agora é preciso interpretar a agricultura como um ecossistema, das redes, da sociabilidade - das tramas -, do interconhecimento e da sua dependência com relação às cidades (Abramovay, 2006; Favareto, 2006). Assim, estudar as feiras livres é estudar a Agricultura Familiar (AF) e suas ruralidades, expressas como territorialidades.

O conceito de território e territorialidade ainda gera algum tipo de confusão e, por isso, merecem ser debatidos. O território é produzido por atores através da energia e da informação, ou seja, da "efetivação no espaço (formação de cada lugar em determinado tempo - presente - passado - futuro) das redes, das relações de poder, das atividades produtivas, das representações simbólicas e das malhas" (Saquet, 2011, p. 79). O território é o espaço social e um espaço real, ou, "na perspectiva fenomenológica de Frémont (1976), o território se impregna de valores culturais refletindo, para cada um, o pertencimento a um grupo localizado”. (Em Pecqueur, 2009, pp. 88-89).

Já as territorialidades são interpretadas como as práticas socioespaciais das pessoas entre si (de poder) e com o meio externo, tanto materiais quanto imateriais. "São as relações sociais simétricas ou dessimétricas que produzem historicamente cada território" (Saquet, 2011, p. 79). Durante o processo de formação do território poderá ocorrer a sua construção, desconstrução e reconstrução, e esse fenômeno territorial é chamado de TDR (Territorialização, Desterritorialização, Reterritorialização). 
Baseado em Saquet (2013), a TDR pode ser explicada como o processo onde a territorialização seria o enraizamento (áreas com fronteiras, Estado-Nação); a desterritorialização seria o rompimento de fronteiras (supressão do território concebido), os deslocamentos e todo movimento que se dá entre os territórios. Já a reterritorialização seria a conquista do novo, de novas identidades. "A reterritorialização é determinada no bojo da desterritorialização (...) o capitalismo não cessa de re-territorializar o que ele desterritorializa em primeira mão" (Saquet, 2013, p. 56). Esse é o efeito que pode ser observado na história das feiras em Corumbá, que já passaram pela TDR, bem como continuam passando, afinal, as relações de poder nunca cessam (Espírito Santo et al, 2017b).

O uso do território é o que caracteriza o surgimento da territorialidade, a relação entre os homens e o território. Esse relacionamento é resultado das dimensões política, cultural, econômica e naturalista. Evidência o pertencimento, a identidade, os conflitos sociais, enfim, as manifestações dos protagonistas e fundamenta-se na noção de proximidade geográfica, que conjetura relações sociais diretas entre os atores. É o resultado dos laços sociais que favorece os estudos dos espaços rurais (Costa, 2011; Haesbaert, 2011; Pecqueur, 200 9; Abramovay, 2006).

Para Schneider (2003), os espaços rurais foram valorizados no processo de desenvolvimento nacional devido ao aumento de políticas públicas voltadas para o desenvolvimento rural. Assim, devem-se conceber os estudos rurais para além do espaço rural, evidenciando os diferentes sujeitos suas territorialidades e suas tramas. A ampliação da visão permitirá interpretar o rural como uma abordagem territorial do desenvolvimento rural (Favareto, 2010), reconhecendo os processos sociais como palco de classes sociais, conflitos, identidade, decisão e poder (Abramovay, 2006). Deve-se "encarar os territórios como campos em que se defrontam protagonistas com interesses diversos” (Abramovay, 2006, p. 10). Logo, a necessidade de estudar os processos localizados de cooperação, pois, é no desenrolar desses interesses que se formam as tramas territoriais.

A abordagem territorial do desenvolvimento rural está em processo de legitimação, decorrente do aumento das pesquisas e das inúmeras políticas públicas criadas pelos governos que fomentam o desenvolvimento dos atores, das organizações e da governança pública. A questão aqui está na emergência de se ampliar a interpretação que se tem do rural. Em países como os da América Latina, a abordagem territorial está concatenada ao processo histórico deste território, logo, transpor modelos e sistemas europeus para cá nem sempre é a melhor solução. Há de se introduzir uma abordagem que compreenda o ecoado aqui: os territórios e as territorialidades para a promoção do desenvolvimento rural (Favareto, 2010).

Transpondo essas análises para os territórios fronteiriços, é necessário que se compreenda o sentido da fronteira para os sujeitos que ali vivem - a fronteira vivida (Espírito Santo, 2018). Para Pecqueur (2009), a proximidade geográfica aparece como uma variável equivalente a capital. Dessa forma, no caso da fronteira, temos de considerá-la como um dos componentes fundamentais para se entender a formação dos territórios e suas construções sociais, as práticas simbólicas e materiais da sociedade. Assim, centrando o olhar para as feiras livres, palco da sociabilidade na fronteira Brasil-Bolívia, defende-se aqui que as feiras devem ser interpretadas como objetos de estudo acadêmico que fomentem a criação de políticas públicas, subsidiando suas "dinâmicas de funcionamento, valorizando seu papel dentro das atividades econômicas, sociais e culturais" (Schneider, 2003, p. 10).

É no interim de todo esse fenômeno descrito que surgem as tramas territoriais aqui estudadas. As complementariedades e oposições entre os territórios desenham o desenrolar do dia a dia dos sujeitos. No caso de uma feira, as tramas se manifestam como relações integrantes entre feirantes e os produtores rurais. A oposição de órgãos reguladores se faz presente, contudo, não inibem a dinâmica sociocultural e econômica das feiras. 


\section{A Feira livre de Corumbá na fronteira Brasil-Bolívia}

A feira livre de Corumbá surge, oficialmente, a partir do Projeto-Lei - Ato no 37 de 12 de junho de 1943. Somente em 5 de maio de 1952 é que a Câmara Municipal consegue consolidar todas as providências necessárias para a criação da feira, com a aprovação da Lei Municipal n ${ }^{\circ} 058$. Sete anos depois, em 3 de maio de 1959, é que o jornal $A$ Tribuna (edição nº 17.731 de 3/5/1960) notícia a primeira feira livre na cidade, mencionando o êxito e a aceitação por parte dos moradores locais. Não há registros na Câmara Municipal que expliquem a razão dessa demora de entrada em funcionamento da feira livre ${ }^{1}$.

A Lei Municipal $n^{\circ} 058$, de 05 de maio de 1952, em seu art. $2^{\circ}$, indicava que a organização e a localização da feira eram atribuições da Prefeitura Municipal. O jornal $A$ Tribuna (edição nº 17.731 de 3/5/1960) menciona que, à época, a feira acontecia em três pontos da cidade: na Praça Uruguai, no Largo da Caixa d'Água e na Rua sete de setembro, entre a Rua Delamare e a Avenida General Rondon. A primeira e a última localizadas no centro da Corumbá (Figura 1).

\section{FIGURA 1}

Localização das primeiras feiras livres de Corumbá

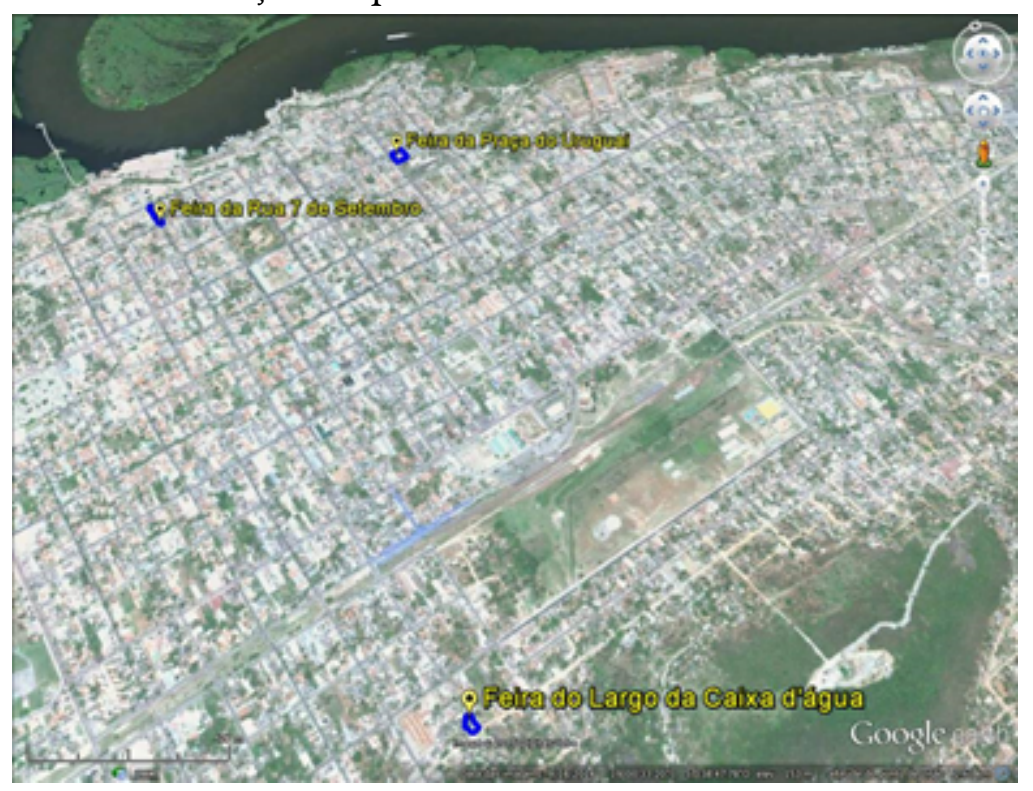

Fonte: Jornal A Tribuna (Edição n 17.731 de 3/5/1960). Org. Espírito Santo, A. L. Google Earth. Image @ 2016 DigitalGlobe.

Silva (2003) aponta que em 1959 a feira livre de Corumbá contava com 133 feirantes no domingo e atraia um grande número de pessoas nos dias de funcionamento, tendo em vista a possibilidade para a aquisição de gêneros de primeira necessidade por menor preço.

A expansão para outras áreas da cidade foi possível a partir da aliança entre os interesses dos feirantes e dos presidentes das associações de bairros. Pesquisas nas edições do jornal $A$ Tribuna e no trabalho de Silva (2003) permitem este entendimento, demonstrando a insatisfação da população que era obrigada a comprar as mercadorias em lugares mais próximos, por vezes mais caras, quando poderiam ser adquiridas nas feiras. A resistência mais efetiva era dos comerciantes locais que viam nelas concorrentes potenciais.

Atualmente, as feiras livres de Corumbá/MS ocorrem todos os dias da semana, espalhadas por diversos bairros da cidade (Figura 2). Em Ladário, cidade vizinha, a feira ocorre três vezes na semana e também tem a mesma configuração que as feiras da cidade de Corumbá.

A feira livre de Corumbá é regimentada pelo Decreto Municipal $n^{\circ} 307$, de 5 de julho de 2007, que regulamenta a organização e define os dias e locais de funcionamento. Na pesquisa de campo foi 
constatado que as feiras cresceram para além do ordenamento, extrapolaram os limites previamente definidos e subverteram a normativa de comercialização com a inserção de produtos de comercialização proibida.

FIGURA 2

Localização das feiras livres nas cidades de Corumbá e Ladário

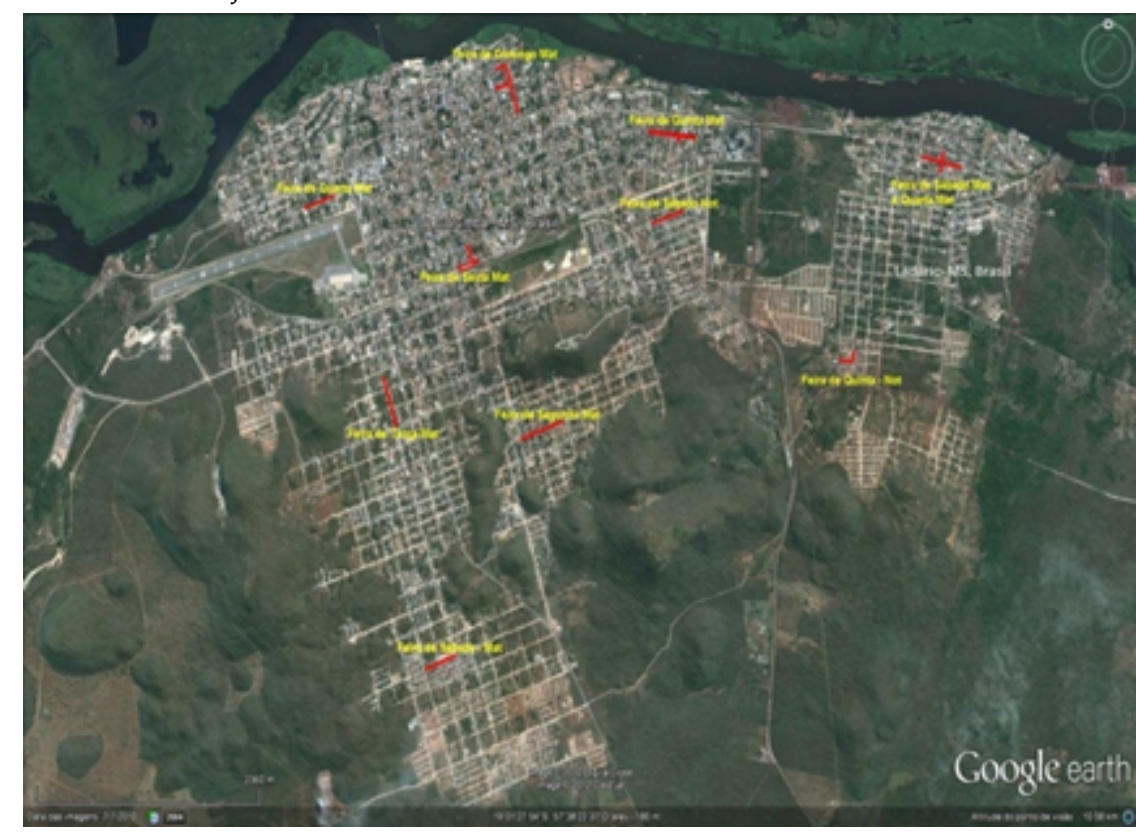

Fonte: Santos e Oliveira (2012, p. 10). Google Earth. Image @ 2014 DigitalGlobe.

O número de feirantes cadastrados informado pela CAC - Central de Atendimento ao Consumidor (órgão da Prefeitura Municipal de Corumbá responsável pelo cadastro dos feirantes) gira em torno de 430. "Em torno de 430" porque o sistema mostra todos, inclusive os feirantes que estão em processos de suspensão e baixa. Contudo, o sistema apresenta apenas 182 ativos, ou seja, feirantes cadastrados e com o pagamento das taxas em dia. Segundo o presidente da Associação dos Feirantes existem cerca de 400 feirantes, incluindo os sem cadastros, os sazonais e os remanescentes da Feira Bras-Bol ${ }^{2}$ (fechada pela prefeitura de Corumbá em 2013).

Não são os mesmos feirantes em todas as feiras, mas parte significativa (mais da metade) deles atua em todas elas. Os bolivianos atuam em todas as feiras, diferentemente dos assentados rurais brasileiros, que preferem as feiras de domingo e de sexta-feira, ampliando o quantitativo de feirantes nesses dias. Na quarta-feira e no sábado pela manhã as feiras livres de Corumbá e de Ladário ocorrem concomitantemente e os feirantes se dividem.

$\mathrm{Na}$ pesquisa de campo realizada em dezembro de 2014 foram contabilizados 354 feirantes no domingo e 329 na sexta-feira. São números superiores aos encontrados na pesquisa coordenada por Pinto et al. (2013) no mês de maio de 2013 na feira livre de domingo, quando foram contabilizados 302 feirantes. Desses foram entrevistados 276, sendo 161 bolivianos (58,3\%), 110 brasileiros, 1 argentino, 1 chileno, 1 libanês e 1 marroquino.

Apesar de se visualizar certo padrão simétrico, as feiras apresentam sensíveis diferenças de local para local. Sato (2007, p. 97) destaca que "as feiras de diferentes bairros exibirão feições diferentes, pois elas se fazem com características do lugar". Seja pelos seus frequentadores, seja pelo arranjo instituído para atrair a atenção deles, as feiras são adaptações para cada localidade onde acontecem. E, além disso, são verdadeiros pontos de encontro da população fronteiriça, confirmando as indicações de Sato (2007).

Ao longo dos tempos, as feiras livres e seus feirantes foram se moldando (territorializando) e se remodelando (por intermédio de mudanças, fechamentos abruptos e de novas ligações - reterritorializando). 
Essa lógica da TDR (territorialização-desterritorialização-reterritorialização), própria do processo de criação de territórios (Saquet, 2013), é parte do cotidiano dos feirantes e das lutas para tornar o espaço seu território. Assim, as feiras livres de Corumbá foram surgindo, se desenvolvendo e ressurgindo, ganhando o corpo e a forma que possuem até o momento (figura 3).

Nas feiras é vendida uma grande variedade de produtos. No levantamento realizado por Pinto et al. (2013) constatou-se que a maioria dos produtos vendidos eram frutas, verduras e legumes $(33,5 \%)$, seguidos de roupas e utensílios domésticos $(32,8 \%)$ e outros (brinquedos, CDS e DVS, bijuterias, perfumaria, ferragens, aviamentos, artesanatos, acessórios para celular, eletrônicos, ervas medicinais, comidas, leite e derivados, entre outros), correspondentes a $33,7 \%$ dos produtos oferecidos

\section{FIGURA 3}

A feira livre de Corumbá
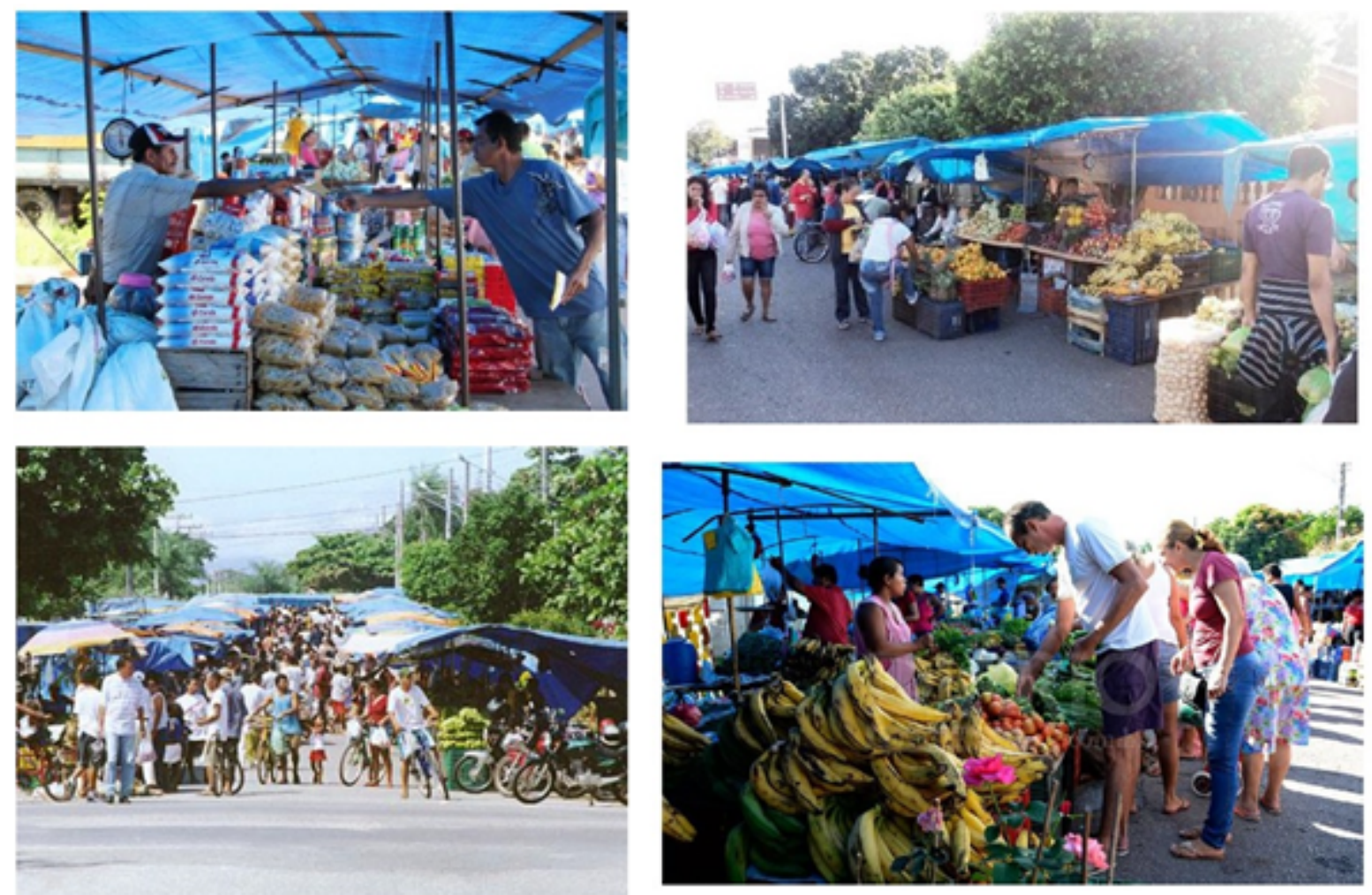

Fonte: Espirito Santo, 2015, pp. 12-58

A pesquisa de campo realizada entre 2014 e 2015 demonstrou que os resultados obtidos por Pinto (2013) ainda são atuais. Contudo, observou-se um aumento de bancas que vendem roupas, motivado pela migração de feirantes após o fechamento da Feira Bras-Bol.

TABELA 1

Quantidade de bancas que comercializam Frutas, Legumes e Verduras (FLV) nas feiras livres de Corumbá/MS

\begin{tabular}{|c|c|c|c|c|c|c|c|c|}
\hline & $\begin{array}{l}\text { Feira de } \\
\text { Domingo }\end{array}$ & $\begin{array}{l}\text { Feira de } \\
\text { Segunda }\end{array}$ & $\begin{array}{l}\text { Feira } \\
\text { de } \\
\text { Terça }\end{array}$ & $\begin{array}{l}\text { Feira } \\
\text { de } \\
\text { Quarta }\end{array}$ & $\begin{array}{l}\text { Feira } \\
\text { de } \\
\text { Euinta }\end{array}$ & $\begin{array}{l}\text { Feira } \\
\text { de } \\
\text { Sexta }\end{array}$ & $\begin{array}{l}\text { Feira de } \\
\text { Sábado } \\
\text { (matutino) }\end{array}$ & $\begin{array}{l}\text { Feira de } \\
\text { Sábado } \\
\text { (noturno) }\end{array}$ \\
\hline FLV & 96 & 49 & 61 & 59 & 49 & 87 & 46 & 25 \\
\hline OUTROS & 258 & 134 & 182 & 92 & 105 & 242 & 106 & 167 \\
\hline TOTAL & 354 & 183 & 243 & 151 & 154 & 329 & 152 & 192 \\
\hline
\end{tabular}


Como observado na tabela 1 , hoje em dia as feiras livres de Corumbá possuem mais bancas que comercializam outros ${ }^{3}$ tipos de produto do que bancas que comercializam produtos agrícolas (FLV) especificamente. Esses números chamam a atenção para entender como ocorre a comercialização de produtos agrícolas na cidade de Corumbá, visto que o objetivo inicial de uma feira livre era o de comercializar o excedente da agricultura familiar, fato este não exclusivo nas feiras de Corumbá. Diversas prerrogativas justificam a grande quantidade de bancas que comercializam outros tipos de produtos, como o fechamento da Feira Bras-Bol. O fato de Corumbá não possuir um camelódromo e ou o comércio de roupas e outros artefatos, em alguns bairros da cidade é baixo. Logo, as pessoas encontram nas feiras livre importante canal varejista para suprir todas as suas necessidades.

\section{Feiras livres de Corumbá: territórios da convivência cultural fronteiriça}

Como se dá a formação das tramas territoriais dentro das feiras livres? Nesta etapa será apresentado que as tramas ocorrem balizadas nas formas de relacionamento existentes. Quando perguntado "como tudo começou?", muitos bolivianos afirmaram que herdaram essa tradição de ser feirante dos próprios pais. "Meu sogro fazia feira há 26 anos. Ficou doente e nós assumimos a feira. Ele iniciou lá na Feira do Boliviano, aquela que fechou (...) depois veio parar nas feiras do dia a dia" (E.1). "Antes meu pai ficava na feira. Como eu cresci com ele fui assumindo as atividades. Meu pai era da feira do Boliviano. Só eu estou aqui há 13 anos, ele já tem quase 30 anos de feira. Depois que fechou a feira do boliviano, nós viemos para cá e cada dia a feira funciona em um local" (E.2). Quanto aos feirantes brasileiros, fica evidente que a origem está concatenada ao movimento Sem-Terra. "Faz 20 anos que sou feirante. Eu e meu marido éramos sem-terra, lá de Itaquirai/MS. Quando chegamos aqui conseguimos ser assentados. No início comprávamos os produtos e revendíamos, hoje temos uma pequena produção" (E.3).

São pessoas que constroem suas vidas de acordo com as possibilidades e com os enfrentamentos individuais e coletivos. Lidam e se aproveitam das oportunidades presentes nos territórios. Segundo Grimson (2000, p. 91), as populações fronteiriças podem e devem ser vistas como agente da própria história, bem como "de mudanças sociopolíticas significativas para além da sua localidade”.

Referente a essas forças dos agentes sociais, E.4, filha de feirantes, atual esposa de feirante e ex-participante da Feira Bras-Bol, expressou o seguinte comentário:

Chegaram e acabaram com a feirinha (em referência à Feira Bras-Bol) (...), também somos brasileiros. Somos filhos desse país (...) vamos viver do que? No ano passado, [depois que fecharam a feira] até a festividade da Santa (Urkupiña) foi fraca. Não conseguimos reunir todos os participantes de anos anteriores. Muitos estavam com raiva do prefeito e outros simplesmente estão correndo atrás de um novo espaço para trabalhar. É muito mais que dinheiro; tem tradição.

A feira representa muito mais que uma necessidade econômica dos feirantes e dos consumidores. Envolve, fortemente, a dimensão sociocultural, os relacionamentos, os encontros. Esses elementos estão presentes nas falas dos dois consumidores, expostas a seguir:

Eu tenho um Opala marrom. Meu carro só sai de casa um único dia da semana. Domingo de manhã para vir na feira. Eu adoro andar com minha esposa. É o nosso passeio. Se isso aqui acabar, ou se tirarem os bolivianos daqui, aonde iremos. Não tem nenhum lugar igual aqui. Faço isso desde que me casei com a minha esposa (E.5).

Se fechar a feira nós ficaremos numa situação péssima. Os produtos são melhores que os do supermercado e mais baratos. Os bolivianos são a feira e sem eles isso aqui não sobreviverá (E.6).

A partir das entrevistas, há alguns elementos que precisam ser analisados como o compartilhamento da cultura, dos símbolos e da religiosidade. Primeiramente, pode-se exemplificar o compartilhamento do portunbol ${ }^{4}$ onde diariamente a comunicação é intensa e a língua não é uma barreira; ao contrário, flui 
com naturalidade. Em segundo lugar, o compartilhamento da religião, onde brasileiros e bolivianos se unem para celebrar as festividades de Nossa Senhora de Aparecida (padroeira do Brasil), Virgem de Urkupiña e Copacabana (Bolívia). Muitas bolivianas disseram que participam/dançam no desfile comemorativo às santas. Informaram que já há alguns anos, também, começaram a distribuir saquinhos de doces na festa de Cosme e Damião (festa tipicamente brasileira e muito presente em Corumbá). A fé une os moradores na fronteira e os cultos e a devoção indicam como a realidade social é construída a partir de símbolos e demais artefatos trocados entres os sujeitos que, neste caso, são exteriorizados pela fé (Espírito Santo, 2018). O terceiro compartilhamento refere-se à comida, onde foi possível encontrar brasileiros e bolivianos comercializando as tradicionais sopas que os bolivianos tanto apetecem. Há uma troca de sabores e temperos de ambos os lados, inclusive nas festas cívicas; conforme E.7: "todos os anos nós, brasileiros e bolivianos, desfilamos no aniversário de Corumbá (...) ascholitas vão dançando e tudo mais. E nós também desfilamos para comemorar o dia 6 de agosto (Independência da Bolívia)". Por fim tem-se o compartilhamento do espaço onde a feira fica caracterizada como ponto de encontro para que ocorram os relacionamentos existentes dentro de uma comunidade.

Este paradoxo cultural pode ser um grande potencial turístico. Costa et al. (2010, p.39) destacam o seguinte ponto referente à diversidade cultural em territórios fronteiriços:

A fronteira é, sobretudo, um lugar marcado pela diferença. (...) A atividade turística vem crescendo e cada vez mais se busca incorporar novos territórios, lugares e, sobretudo, o diferente. Assim sendo, a fronteira significa potencialidade, pois contempla o diverso, o diferente. (...) A fronteira ainda é vista como uma palavra tingida por um forte etnocentrismo cultural.

Outra força dos agentes sociais, idealizados por Grimson (2000), que merece destaque é o papel das associações e da Prefeitura neste território. Os feirantes possuem uma associação na cidade de Corumbá. Quando perguntados: “participa de associações ou cooperativas?”,todos responderam que sim, que fazem parte da Associação de Trabalhadores Autônomos das Feiras Livres de Corumbá e Ladário. Um ponto que merece destaque é o fato de alguns bolivianos terem respondido "sim, eu participo da Associação 2 de Mayo". Esta associação é dos feirantes que trabalham em Puerto Quijarro e Puerto Suárez, referente às atividades desenvolvidas lá. Segundo E.7, "essa associação não tem jurisprudência nem amparo legal para intervir no Brasil. Só nós podemos ajudar e interpor qualquer ato/defesa que represente os feirantes. Hoje estamos mais organizados e temos até um estatuto próprio”.

Na pergunta "há incentivo para a formação de grupos de defesa dos interesses dos feirantes?", os feirantes disseram que não veem a atuação da Associação e que, por ora, todos só aguardam as decisões (sobre fechamento e funcionamento das feiras) que serão tomadas. Portanto, não há nada planejado/estruturado. $\mathrm{Na}$ conversa com o presidente da associação dos feirantes ficou evidente que eles não têm nenhuma defesa/ argumento pronto, por escrito, para manutenção dos seus interesses.

A feira é um território para o qual confluem territorialidades dos agentes sociais da fronteira BrasilBolívia, desterritorializadas e reterritorializadas cotidianamente. As territorialidades estão sendo entendidas no sentido de práticas socioespaciais das pessoas entre si (de poder) e com o meio externo, tanto materiais quanto imateriais (Saquet, 2011). A fala, a seguir, demonstra as habilidades para utilização dos territórios das feiras e as motivações proporcionadas pelas assimetrias dos territórios fronteiriços:

É muito fácil ser feirante em Corumbá. Você chega, se infiltra, quando os fiscais passarem você tem a chance de não ter as mercadorias apreendidas. Você é encaminhado para a Prefeitura para realizar o cadastro. Paga um valor simbólico e tudo bem. Durante muito tempo a Associação 2 de Mayo infiltrou diversos feirantes aqui na feira de Corumbá. Claro, lá é muito mais difícil de ser feirante e o pagamento é em dólar (3 mil dólares o período, fora taxas de manutenção/segurança). A nossa associação não vê bolivianos ou brasileiros. Somos todos feirantes e queremos o nosso espaço para trabalhar. Concordo que falta sim um melhor ordenamento da feira. Para nós da associação, na feira só poderia trabalhar quem é brasileiro ou boliviano que já tem residência comprovada na cidade (até com filhos brasileiros). Estes são cadastrados e até gastam seu dinheiro no nosso comércio. Fazem a nossa economia girar. A Bolívia é mais bem considerada do que Corumbá, veja o quanto as cidades do lado de lá estão crescendo e a nossa não vai para frente (E.7, presidente da associação dos feirantes). 
O então presidente da Associação Comercial de Corumbá destacou que entende a importância das feiras livres e da presença dos bolivianos como feirantes. Contudo, percebe-se na sua fala a preocupação com a regularização de funcionamento, principalmente quanto à formalização dos feirantes como microempreendedores individuais. No fundo, por trás de suas palavras reside insatisfação quanto às diferenças de pagamento de impostos dos empresários em relação a estes, conforme se pode observar:

A feira livre é essencial para Corumbá, porque nela encontramos produtos frescos, preços acessíveis e a própria presença dos bolivianos, que não pode ser ignorada. Contudo, as feiras de Corumbá são mal organizadas e possuem péssima fiscalização. Há necessidade de ter mais higiene, banheiros químicos e limpos, um quiosque padronizado; a presença da guarda municipal. Eu não concordo com a desorganização da feira. A feira precisa se reorganizar e os feirantes têm que ser cadastrados junto à prefeitura e serem formalizados como microempreendedores individuais (E.9, presidente da Associação Comercial de Corumbá).

As relações de trabalho expõem as diferenças culturais entre feirantes bolivianos e brasileiros e com os fiscais da Prefeitura de Corumbá. Culturalmente, as crianças bolivianas acompanham seus pais para o trabalho e aprendem, desde cedo, a arte da venda. No Brasil, as crianças são proibidas de trabalhar. A feira expõe esse conflito, como se pode notar na fala de um fiscal:

A feira é importante. A preocupação nossa, fiscais de postura do município, a cada dia aumenta mais. Todo dia a gente tenta pôr na cabeça dos feirantes que o dizer feira livre não significa que é para vender de tudo. Tem muita coisa ilícita, sem origem, falta de higiene e constante presença de crianças. Esses dias uma barraca quebrou e a criança estava embaixo da barraca dormindo (E.10, fiscal de postura do Município).

A partir dos relatos acima é possível compreender que a feira é um território o qual confluem territorialidades dos sujeitos localizados na fronteira Brasil-Bolívia. As tramas, nesta primeira parte, surgem a partir das trocas culturais e do cotidiano, e se fazem presentes no dia a dia das feiras de forma histórica. A ruralidade denota que os espaços rurais estão em processos de revitalização, para além da zona rural, a partir da revalorização da vida no campo, disseminados por novos formatos de espaço rural, como as feiras (Manzanal, 2006). São as temporalidades tratadas por Saquet (2011, p. 79) como ritmos diferentes, "desigualdades econômicas, diferentes objetivações cotidianas e, ao mesmo tempo, distintas percepções dos processos e fenômenos”. As temporalidades e as territorialidades são históricas e relacionais/coexistentes, e expressam as tramas territoriais das feiras livres em Corumbá, carregadas das impressões dos fronteiriços.

\section{As tramas terRitoriais de AGRICULTORES E VENDEDORES DE HORTALIÇAS NAS FEIRAS De Corumbá}

Nesta etapa serão apresentados os resultados da pesquisa que materializam as tramas territoriais existentes entre os agricultores e vendedores de hortaliças, brasileiros e bolivianos, nas feiras de Corumbá.

Pinto et al. (2013) identificaram que a maioria dos produtos comercializados na feira é de origem boliviana (51,1 \%). O presente estudo confirmou a pequena participação de produtores rurais de Corumbá (15,2 \%) e, portanto, o aparente desvirtuamento da proposta original da feira ser um mecanismo de escoamento dos excedentes de produção da agricultura familiar, conforme preconizado por Santos (2009).

Contudo, contrariando as aparências, se os bolivianos são os principais vendedores, a maioria dos produtos comercializados na feira são de origem brasileira. Esta pesquisa vem demonstrar que os grandes atacadistas de Corumbá abastecem as feiras livres da cidade. Em entrevista, o presidente da Associação Comercial de Corumbá afirmou: "tenho conhecimento de que brasileiros são fornecedores dos bolivianos" (E.9). Numa banca, a feirante (E.12) explicou que até o alho, produto tipicamente boliviano, está sendo comprado dos atacadistas brasileiros. "Em Santa Cruz [Bolívia] está tudo muito caro (...) ainda tem produto que está vindo de lá, mas muita coisa é daqui do Brasil mesmo, de Corumbá ou Campo Grande”. 
Os camponeses dos assentamentos rurais de Corumbá e Ladário também entregam hortaliças para os bolivianos, especialmente aqueles que não têm condições de se deslocarem até a cidade. Assim, o produto vendido pelos bolivianos nem sempre é oriundo daquele país. Boa parte vem dos assentamentos rurais e da Central de Abastecimento de Mato Grosso do Sul (CEASA-MS) e da Companhia de Entrepostos e Armazéns Gerais de São Paulo (CEAGESP). Porém, nem todos os vendedores de hortaliças são produtores rurais. Durante as entrevistas realizadas nas feiras foi identificado que a maioria das bancas possui comerciantes de FLV. Poucas possuem, efetivamente, um produtor rural a sua frente, como apresentado na tabela 2:

TABELA 2

Quantitativo de produtores rurais encontrados nas feiras livres de Corumbá-MS

\begin{tabular}{|l|l|l|l|l|l|l|l|l|}
\hline & Feira de & Feira de & $\begin{array}{l}\text { Feira } \\
\text { Domingo } \\
\text { Segunda } \\
\text { Terça }\end{array}$ & $\begin{array}{l}\text { Feira } \\
\text { de } \\
\text { Quarta }\end{array}$ & $\begin{array}{l}\text { Feira } \\
\text { de } \\
\text { Quinta }\end{array}$ & $\begin{array}{l}\text { Feira } \\
\text { de } \\
\text { Sexta }\end{array}$ & $\begin{array}{l}\text { Feira de } \\
\text { Sábado } \\
\text { (matutino) }\end{array}$ & $\begin{array}{l}\text { Feira de } \\
\text { Sábado } \\
\text { (noturno) }\end{array}$ \\
\hline $\begin{array}{l}\text { Produtor } \\
\text { Rural } \\
\text { Brasileiro }\end{array}$ & 44 & 12 & 12 & 14 & 21 & 19 & 21 & 3 \\
\hline $\begin{array}{l}\text { Apenas } \\
\text { Comerciante } \\
\text { De FLV }\end{array}$ & 52 & 37 & 49 & 45 & 28 & 68 & 25 & 21 \\
\hline TOTAL & 96 & 49 & 61 & 59 & 49 & 87 & 46 & 25 \\
\hline
\end{tabular}

Fonte: Dados da Pesquisa.

Destarte, referente à tabela 2, observa-se que a presença de produtores rurais se dá, em maior número, na feira de domingo - a maior e a mais tradicional feira da cidade. Referente a estes produtores rurais foi perguntado a qual assentamento pertenciam. O assentamento Taquaral é o que possui maior presença nas feiras, conforme apresentado na figura 4

FIGURA 4

Origem dos produtores rurais da feira livre de Corumbá e Ladário

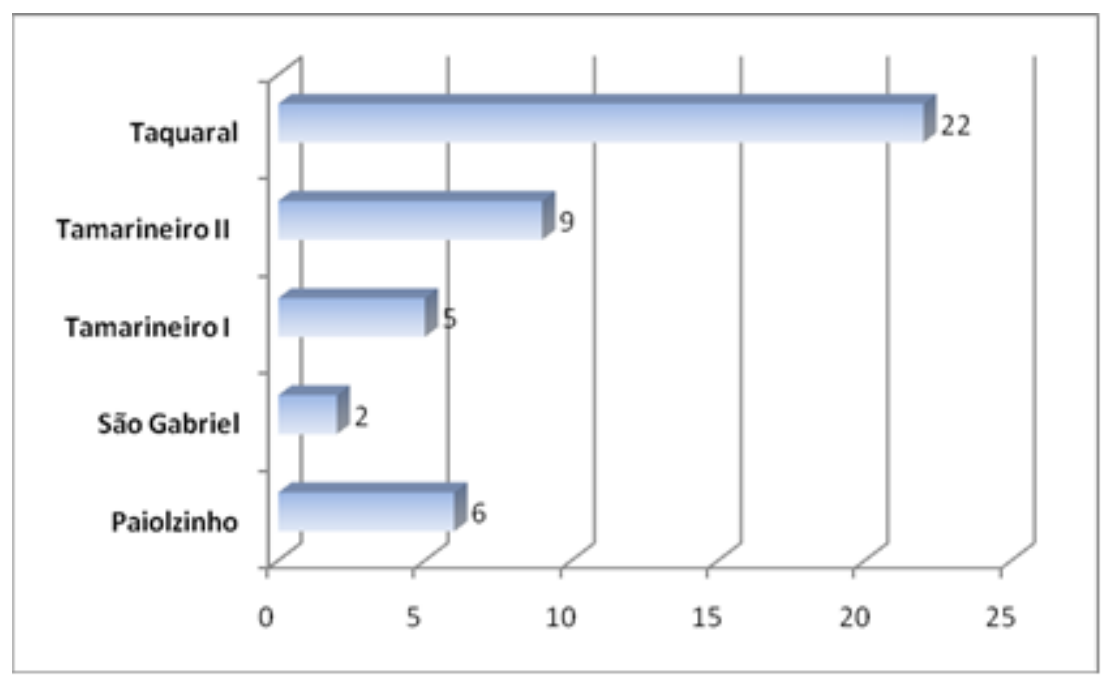

Fonte: Dados da Pesquisa.

O assentamento Taquaral é o mais próximo do espaço urbano de Corumbá, perto do bairro Nova Corumbá, aonde ocorre à feira de sábado (manhã) e onde foram encontrados vários produtores que levam seus produtos de carroça, aproveitando a proximidade geográfica. 
Ainda com relação aos produtos, os dados apresentados por Pinto et al. (2013), podem ser cruzados com a visita nas feiras (trabalho de campo) e com a pesquisa de Souza (2010), que realizou um estudo sobre as hortaliças de origem boliviana ofertadas nas feiras livres de Corumbá. Segundo a autora, tanto em Puerto Quijarro como Puerto Suárez destacam-se o cultivo do milho, do feijão e da mandioca. Esses cultivos são para a própria subsistência da família e o excedente é comercializado junto com as frutas, verduras e legumes nas feiras livres de Corumbá. Contudo, vale ressaltar que durante a execução dessa pesquisa, ao serem questionados sobre a origem dos produtos comercializados na feira (principalmente frutas, verduras e legumes), os feirantes bolivianos não souberam dizer se existe presença de agrotóxicos. Os feirantes informam que de Puerto Suárez e Puerto Quijarro vêm às hortaliças e as ervas medicinais vendidas na feira (Figura 5).

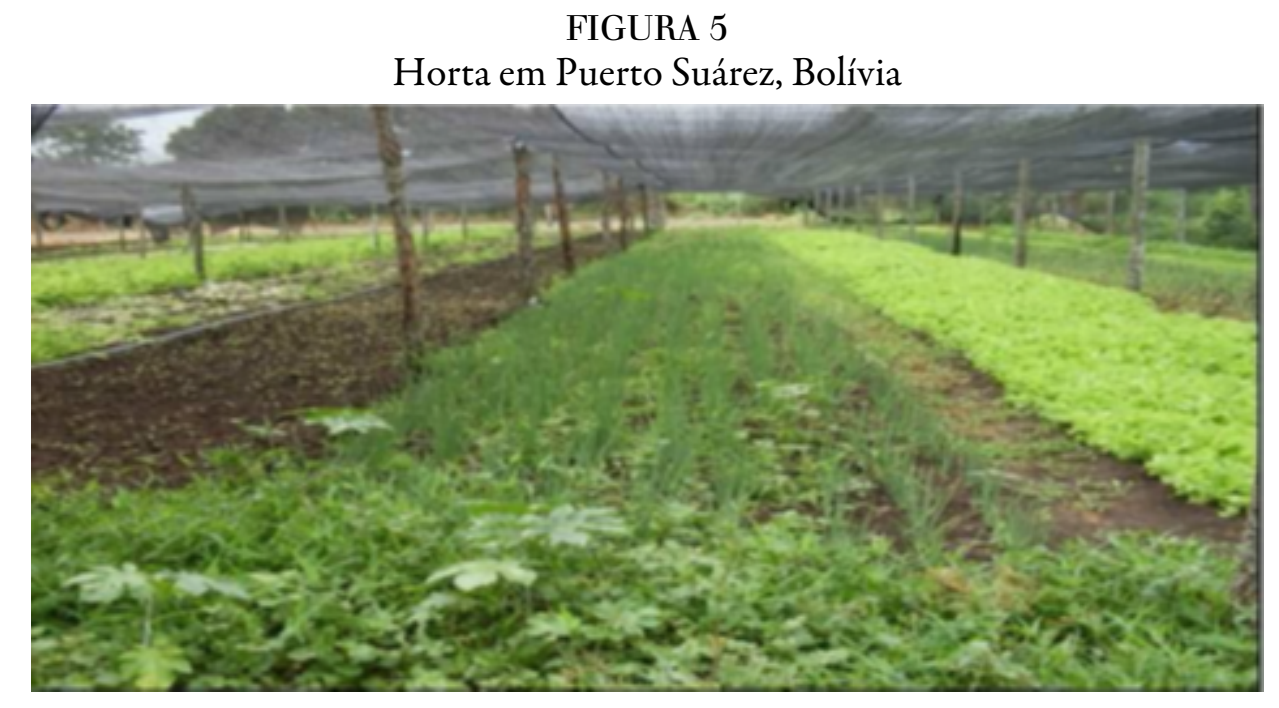

Fonte: Souza, 2010, p. 32

Sobre a comercialização de produtos agrícolas vale destacar que a feira livre não é o único canal que os produtores rurais brasileiros possuem. Estes ainda comercializam na feira do produtor rural e com os programas federais.

A feira do produtor rural foi criada pela Prefeitura de Corumbá em 10 de agosto de 2013, contendo 40 produtores cadastrados e 23 ativos na feira. Nesta feira não tem a participação do boliviano e podese comercializar apenas produtos cultivados pelos próprios produtores (FLV), ervas medicinais, doces, temperos. É proibida a venda de ovos, leites e carnes. Já os programas federais são oriundos de políticas públicas do Governo Federal - GF, que visa reduzir a pobreza e garantir a soberania alimentar. Neste programa, destaca-se o Programa de Aquisição de Alimentos - PAA, onde o governo federal adquire alimentos da agricultura familiar e destina para creches, escolas dentre outras.

Nas entrevistas, quando perguntado aos feirantes brasileiros (tanto aos feirantes da feira livre quanto da feira do produtor) como é o seu relacionamento com os feirantes bolivianos, a maioria elogiou dizendo que há trocas entre eles e que alguns produtos revendidos pelos próprios produtores brasileiros (nas feiras livres) são entregues pelos bolivianos. "Sou contra e não quero que os bolivianos sejam retirados da feira (...) o sol nasceu para todos, aqui tem espaço para todo mundo" (E.8). "Comecei a vender meus produtos aqui na feira do produtor (...) é uma ótima iniciativa, mas não precisa tirar os bolivianos da feira nem de Corumbá, o nosso diferencial é que, além de vender para as pessoas da cidade, só nós podemos vender para o governo, eles não" (E.11).

A fala do último feirante expressa uma série de programas da Agricultura Familiar que visa ajudar o pequeno produtor rural, como Programa Nacional de Fortalecimento da Agricultura Familiar (PRONAF), Mais Alimentos, Programa de Aquisição de Alimentos (PAA), Programa Nacional de Alimentação Escolar (PNAE), dentre outros. Esses programas são fundamentais para os agricultores, bem como para a economia 
local. Segundo Braudel (1998), os produtores rurais e feirantes gastam tudo ou parte do que recebem no comércio da cidade, favorecendo a permanência do dinheiro na esfera municipal. Este cenário é visto frequentemente na própria feira.

A presença do agrotóxico, a falta de certificação da origem do produto, a questão da higiene e o duelo entre legal - ilegal são presentes e frequentes na discussão sobre a entrada de produtos estrangeiros no território brasileiro. Referindo-se a essa problemática, Souza (2010, p. 26) atesta que:

Quanto ao uso e aplicação dos fungicidas/inseticidas nas hortas, os produtores bolivianos de hortaliças alegaram não saberem o grau de toxidade dos mesmos e nem dos perigos que estes produtos podem acarretar para eles e suas famílias assim como também para o meio ambiente (p.24) (...) No Brasil existe legislação que regula, ou proíbe o uso desses produtos, e obriga o produtor a devolver as embalagens usadas, através de decretos e leis, criados para a proteção do meio ambiente e para a manutenção saúde humana. Lei N 6.938, de 31 de agosto de 1981 (Da Política Nacional do Meio Ambiente).

A análise da estruturação dos supermercados na cidade possibilita um maior conhecimento da organização e da dinâmica da cidade. Fica claro por este momento histórico (e recente, 2012) e pelas visitas realizadas nas feiras que a quantidade de produtos produzidos pelos produtores brasileiros não é capaz de abastecer a cidade. Isso comprova a importância dos bolivianos nas feiras (Espírito Santo et al. 2017a). Segundo Corumbá (2013), no dia da abertura da Feira do Produtor: "O preço está bom. Não tem tudo que a gente encontra na feira, mas está com preço em conta, afirmou A. M. M. moradora da cidade”. Como vimos à feira do produtor não tem todos os produtos vendidos na feira livre. A questão da fronteira, presença ou não dos bolivianos, evidencia muito o estudo de Costa e Oliveira (2014, p. 58) ao afirmarem:

A visão da fronteira pelas pessoas que estão nessa zona, geralmente provoca sentimentos de discriminação do fronteiriço, por ele residir em um local onde são permitidas as mais diversas contravenções, o que permite que ele seja visto como suspeito e indigno de confiança. $\mathrm{Na}$ imaginação do "outro", do que está distante dessa situação, a fronteira é lembrada pelos fatos ruins, e não por suas qualidades.

Explicar a heterogeneidade e a multiplicidade de relações existentes neste território fronteiriço é uma tarefa muito difícil. A abordagem territorial foi um caminho fundamental para entender a feira livre e as tramas territoriais, ou seja, as relações de complementaridade e oposição entre brasileiros e bolivianos nas feiras livres da cidade. Daí a necessidade de se entender o que é legal ou ilegal na comercialização de produtos agrícolas em um território fronteiriço.

\section{Entre a Legalidade E A Necessidade}

Esta última parte do trabalho busca analisar como ocorrem as tramas sociais nas dobras e percursos do legal e da necessidade. Foi constatado que nesta fronteira o rigor da legalidade, diariamente, é subvertido. Moradores deste território fronteiriço fazem do comércio com a Bolívia uma extensão do comércio corumbaense conduzidos pelo melhor preço. Da mesma forma nota-se a presença de bolivianos comprando produtos brasileiros, o que se faz ajustar essa reciprocidade em relação a trocas econômicas locais. Assim as tramas das cidades fronteiriças vão sendo construídas a partir das necessidades sociais básicas, neste caso, representada pela aquisição de alimentos, fundamentalmente.

A fronteira é um local que permite variados convívios de grupos de imigrantes, impulsionados por diferentes motivos, em momentos históricos específicos e com interesses particulares. A fronteira é palco de união e crescimento mútuo. Todavia também é palco de legalidades e ilegalidades. Nos dizeres de Grimson (2000, p. 3):

En las fronteras la tensión entre legalidad e ilegalidad es parte constitutiva de la vida cotidiana. Las transacciones comerciales entre las poblaciones son consideradas muchas veces como "contrabando" por los Estados mientras es la actividad más natural para la gente del lugar. 
O comércio, legal ou ilegal - e até ilícito -, é um dos principais propósitos que incentiva as mobilidades existentes nas regiões fronteiriças. "El límite político internacional es el contorno del espacio definido a partir del centro de poder (...) pero el límite no impide el ingreso ni el egreso. Para eso está la frontera" (Benedetti, 2011, p. 2).

Foi perguntado aos feirantes bolivianos: "você está cadastrado junto a Prefeitura"? Todos foram unânimes em responder afirmativamente. Muitos fizeram questão de mostrar o boleto pago, referente à tarifa mensal do cadastramento. Diante dessa situação surge uma nova questão: o boliviano, enquanto cadastrado pela prefeitura municipal brasileira, pagando sua tributação e vendendo produtos comprados de atacadistas brasileiros (que inserem no preço de venda os impostos que devem ser pagos ao governo) está legal, aos olhos da legislação vigente? Tudo indica que sim, afinal os tributos estão sendo pagos. Mais uma vez fica evidente a necessidade de um diálogo e de uma política pública adequada às particularidades da feira fronteiriça.

É nesse ponto que está um dos vários problemas existentes nas feiras de Corumbá. A ilegalidade e o desconhecimento (ou descaso), por parte do governo brasileiro, da origem e certificação do produto. Quando questionados sobre estar legal ou ilegal, tanto os bolivianos quanto os consumidores brasileiros não veem esse comércio como ilegal. Sempre alegam a seguinte afirmativa: "Nós só queremos trabalhar, não estamos fazendo nada de errado". Tal expressão se repete na fala de inúmeros feirantes indo ao encontro das palavras de Costa e Oliveira (2014, p. 210):

\begin{abstract}
Assim, entende-se que o fato de as pessoas não considerarem ilegais algumas práticas, não quer dizer que elas não o sejam; em outras palavras, a distinção entre o legal e o ilegal existe na prática, exerce efeitos sociais e está materializada em códigos e leis. (...) o nosso interesse principal é o de compreender como os limites da lei são negociados por parte das pessoas envolvidas nessas diferentes atividades a que chamaremos de esquemas.
\end{abstract}

Dessa forma as tramas sociais das cidades são marcadas por jogos de relações de poder e de força que "se processam nas fronteiras incertas do informal, do ilegal e também do ilícito" (Telles, 2010, p. 171). O "esquema”é uma atividade presente em todo território fronteiriço do Brasil. Costa e Oliveira (2014, p.213) definem esquema não como algum sinônimo de crime organizado, ou máfia. Interpretam como "a mesma lógica dos negócios capitalistas em que os atores sociais operam como empreendedores (...) possuindo liderança, de um negócio recebedor de lucro, com componente de inovação e com capacidade para superar as incertezas".

Isso quer dizer que em muitas ocasiões nem todos os indivíduos integrantes se conhecem, mas todos compartilham de operações secretas, ou de parte do segredo. Nem todo esquema é uma máfia, mas toda máfia necessariamente tem seus esquemas (Costa e Oliveira, 2014, p.213).

Vale destacar que, além da ilegalidade de produtos agrícolas (sem a certificação da origem), tem a questão da venda de roupas usadas, que chegam à Bolívia através de doações dos Estados Unidos e da Europa e que deveriam ser entregues às famílias carentes (Ferreira, 2015). Essas vendas são proibidas na Bolívia. Contudo, o mercado no Brasil é promissor e sem nenhuma fiscalização. Nas feiras de Corumbá o ilegal se torna legal e ganha o gosto popular e o apoio das mídias, tal qual matéria veiculada pelo jornal Diário Corumbaense (principal jornal da cidade), em 21 de junho de 2011, sendo replicada na íntegra no jornal online Midiamax News (Jornal online da Capital do Estado), conforme apresentado na figura 6.

Outro problema se refere à imigração, já que muitos feirantes moram na Bolívia e estão entrando e saindo todos os dias, com pouca ou nenhuma fiscalização. Durante as entrevistas foram encontrados chilenos e até coreanos, que estão com o visto vencido, residem em Puerto Suárez (cidade localizada a $15 \mathrm{~km}$ de Corumbá) e atravessam todos os dias o limite internacional para trabalhar nas feiras em Corumbá. Esse fenômeno social só pode ser entendido no contexto da migração pendular transfronteiriça - o ir e vir diário entre os países. Aqui temos um importante fenômeno que deve ser alvo de inúmeros estudos, contudo, os pesquisadores sociais de todos os cantos do mundo apresentam lentidão para explicar o fenômeno da imigração (Massey et al., 1998). Uma última questão (não que reflita o último problema em uma feira que apresenta uma enredada 
gestão) são os feirantes - tanto brasileiros quanto bolivianos - que não são cadastrados junto à prefeitura, logo, não pagam tributos sobre a concessão e as vendas realizadas.

FIGURA 6

Comércio de roupas usadas nas feiras de Corumbá

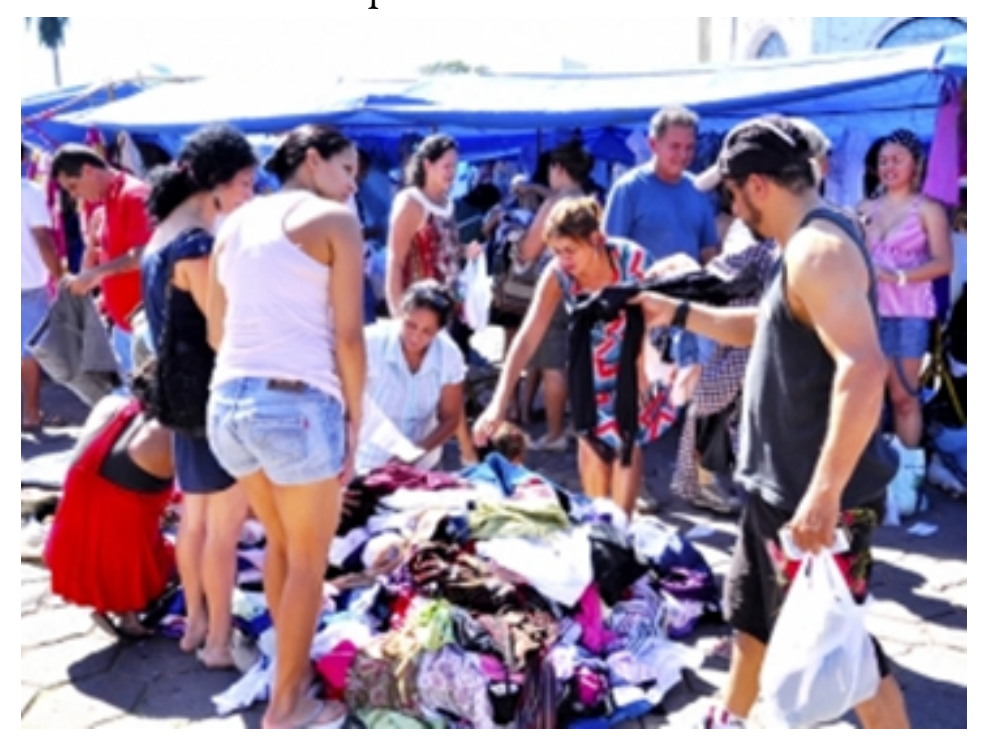

Fonte: Santos e Oliveira, 2012, p. 13.

Totalmente imbricado de relações é o espaço onde se comercializam os produtos da agricultura familiar brasileira e boliviana fronteiriça. Em que pese à força das ilegalidades e da complexidade das territorialidades manifestadas, a feira é fundamental para a cidade. É preciso discutir suas problemáticas de forma multidimensional, pois existem elementos particulares a cada uma das dimensões de análise. Do ponto de vista econômico, possibilita às famílias corumbaenses encontrarem produtos com preços satisfatórios e aos produtores e feirantes vender e escoar a sua produção. Contudo, conflita com interesses de outros comerciantes da cidade quando comercializa outros produtos que não agrícolas e artesanatos. Por outro lado, os feirantes recolhem taxas aos cofres públicos, logo não são plenamente ilegais.

\section{Considerações Finais}

Os resultados desta pesquisa demonstraram que o espaço fronteiriço analisado é marcado por intensa fluidez, caracterizado por frequente mobilidade humana, trocas comerciais, compartilhamento cultural e outras manifestações coletivas. Nesse conjunto de cidades fronteiriças, Corumbá se diferencia das outras três (Ladário, Puerto Quijarro e Puerto Suárez) por apresentar uma melhor infraestrutura e oferta de serviços. Além disso, possui o dobro da população de todas elas, tornando-se um importante mercado consumidor. Todas essas manifestações vão impactar e desenhar as tramas territoriais na fronteira Brasil-Bolívia. A trama social, advinda da intensa sociabilidade fronteiriça, se apoia nas práticas dos atores e configura os espaços urbanos, neste caso, a feira livre de Corumbá.

Seguindo as pistas que eram entregues pelos próprios atores (durante a realização das entrevistas) atrelado ao desenho da trajetória da feira livre neste território (a partir do levantamento documental/histórico) foi possível reconhecer como se dá o processo de comercialização de produtos agrícolas na fronteira BrasilBolívia. Observou-se que a agricultura familiar é de suma importância para este território fronteiriço, visto que há grande demanda por abastecimento de alimentos. Contudo, a quantidade produzida pelos agricultores familiares brasileiros é insuficiente para abastecer o mercado local. Logo, faz-se necessária a 
entrada de produtos de outros territórios, como de Santa Cruz (Bolívia), Campo Grande, Curitiba e São Paulo (Brasil), dentre outras, que serão comercializados nas feiras.

Através dos relatos ficou evidente como ocorrem as tramas sociais nas dobras do legal, ilegal e da necessidade, a partir do relacionamento e da cooperação entre os atores na fronteira Brasil-Bolívia. "Alguns atores são mais habilitados socialmente em obter a cooperação dos outros, em manobrar em torno de atores poderosos e em saber como construir coalizões políticas na vida" (Abramovay, 2006, p. 8). É importante que os atores não sejam apenas reprodutores das estruturas, mas que tenham capacidade de alterar a correlação de forças dentro de um determinado campo, neste caso, as feiras.

A partir dessa problemática poderão ser (re)construídos novos relacionamentos, obrigações e obrigatoriedades com base na cooperação. É fundamental, então, não "só compreender a maneira como os atores se inserem em certas realidades e mesmo em certos papéis sociais, mas também como adquirem o poder de alterar as relações de forças dos campos em que estes papéis são desempenhados" (Abramovay, 2006, p. 8). As dificuldades de integração precisam ser rompidas a partir do diálogo e da ação pública que dará visibilidade aos desafios públicos (comercialização de produtos agrícolas) e aos esforços para resolvê-los em territórios fronteiriços, frente aos desafios da soberania nacional. Por tudo isso, a importância de se tecer estudos e políticas públicas sobre a abordagem territorial e que, neste caso, priorizem o espaço rural e fronteiriço.

Nesse sentido, a formação das tramas territoriais ocorre a partir da experiência de múltiplos atores: consumidores, varejistas, agricultores, poder público, dentre outros, na escala nacional e internacional, que se complementam e se opõem nas relações diárias e nos jogos de poder do território. Todas essas linhas se entrecruzam nas redes sociais e, nesse jogo, tantas outras conexões e circuitos se embaralham ainda mais, nas fronteiras do legal, ilegal e da necessidade.

Em territórios fronteiriços as proximidades e os fluxos diários podem gerar potencialidades de crescimento mútuo, daí a necessidade da mobilização para buscar dirimir um determinado problema. A fronteira precisa ser entendida como um local de encontro, de união, e não como pontos antagônicos que possam gerar qualquer fechamento e ou, obstáculo. O trabalho do boliviano nas feiras livres de Corumbá deixa evidente que percebem a fronteira do ponto de vista dos fluxos humanos como espaço vivido. A fronteira assume um caráter simbólico para os feirantes, e os limites, em nada impede suas territorialidades.

\section{REFERÊNCIAS}

Abramovay, R. (2006). Para uma teoria dos estudos territoriais. Em M. Manzanal, G. Neiman e M. Lattuada (Org.), Desarrollo rural: Organizaciones, instituciones y territórios (pp. 1-13). Buenos Aires: Ediciones Ciccus.

Benedetti, A. (2011). Lugares de frontera y movilidade comerciales en el sur sudamericano: una aproximación multiescalar. Em E. A Costa, G. V. L. Costa, M. A. M. Oliveira (Orgs.), Fronteiras em foco, 2(1) (pp. 53-47). Campo Grande: Editora da UFMS.

Braudel, F. (1998). Os Jogos das Trocas. São Paulo: Martins Fontes.

Decreto Municipal n ${ }^{\circ}$ 307, de 05 de julho de 2007. (2007). Dispõe sobre a organização e funcionamento das feiraslivres de Corumbá. Corumbá, MS. Em Arquivo da Câmara dos Vereadores de Corumbá-MS.

Corumbá. (2013). Feira do Produtor é aprovada e atende população corumbaense. Disponível em: http://www.co rumba.ms.gov.br/noticias/feira-do-produtor-e-aprovada-e-atende-populacao-corumbaense/14686 (consultado em maio 2018).

Costa, E. A. (2011). Mexe com o que? Vai pra onde? Constrangimentos de ser fronteiriço. Em E. A. Costa, G. V. L. Costa, M. M. M. Oliveira (Orgs.), Fronteiras em foco, 2(1) (pp.131-170). Campo Grande: Editora da UFMS.

Costa, E. A. et al. (2010). Fronteira: limite ou potencialidade para as práticas do turismo? Seminário de Estudos Fronteiriços (SEF), 13-25.

Costa, G. V. L. (2013). O muro invisível. A nacionalidade como discurso reificado na fronteira Brasil-Bolívia. Tempo Social-Revista de Sociologia da USP, 25(2), 141-156. 
Costa, G. V. L., Oliveira, G. F. (2014). Esquemas de fronteira em Corumbá (MS): Negócios além do legal e do ilegal. Dilemas: Revista de Estudos de Conflito e Controle Social, 7(2), 207-332.

Espirito Santo, A. L. (2015). A comercialização de produtos agrícolas em Corumbá-MS: propostas para o fortalecimento da agricultura familiar e da feira livre (Dissertação de mestrado), Universidade Federal de Mato Grosso do Sul, Corumbá, MS, Brasil.

Espirito Santo, A. L. (2016). Os supermercados na cidade de Corumbá-MS: uma análise sobre suas origens e fatos históricos. Revista GeoPantanal, 4(20), 105-124.

Espirito Santo, A. L. et al. (2017a). Possibilidades de gestão compartilhada de territórios fronteiriços: Reflexões a partir das feiras livres de Corumbá, Brasil. Revista Espacio. 38(17), 30-45.

Espirito Santo, A. L. et al. (2017b). A feira livre de Corumbá-MS na fronteira Brasil-Bolívia. Boletim Geográfico. 35(3), 93-108.

Espirito Santo, A. L. (2018). O uso de Fotografias e Vídeos em Pesquisa Qualitativa: em busca de um novo olhar sobre os Territórios Fronteiriços. Anais do VI Encontro de Ensino e Pesquisa em Administração e Contabilidade (EnEPQ) (pp.1-10). Porto Alegre-RS: ANPAD.

Faulstich, E. (1997). O portunhol é uma interlíngua? Seminário apresentado no Institut Universitari de Linguistica Aplicada (IULA), (pp.12-16). Barcelona, Espanha: Pompeu Fabra.

Favareto, A. (2006). Paradigmas do desenvolvimento rural em questão - do agrário ao territorial (Tese de doutorado), Universidade de São Paulo, São Paulo, SP, Brasil.

Favareto, A. (2010). A abordagem territorial do desenvolvimento rural - mudança institucional ou "inovação por adição"? Estudos Avançados, 24(68), 299-319.

Ferreira, F. L. (2015). "Brechó Fronteiriço": a comercialização de roupas usadas nas feiras livres de Corumbá (BR) (Dissertação de mestrado), Universidade Federal de Mato Grosso do Sul, Corumbá, MS, Brasil.

Grimson, A. (2000). Pensar fronteras desde las fronteras. Revista Nueva Sociedad. 1(170), 1-5.

Haesbaert, R. (2011). O Mito da Desterritorialização: Do fim dos territórios à multiterritorialidade (6a). Rio de Janeiro: Bertrand Brasil.

Jornal a Tribuna (1960, Maio, 03). Feira-livre de Corumbá comemora 1 ano. Jornal A Tribuna, (17.731), p.A.6.

Manzanal, M. (2006) Regiones, territorios y institucionalidad del desarrollo rural. Em M. Manzanal et al, Desarrollo Rural: Organizaciones, Instituciones y Territorio (pp.21-50). Buenos Aires: ed. CICCUS.

Massey, D. S. et al. (1998). Worlds in Motion: understanding international migration at the end of the millennium. London: Oxford University Press

Pecqueur, B. (2009). A guinada territorial da economia global. Revista Politica \& Sociedade, 8(14), 79-105.

Pinto, J. S. et al. (2013). Os Aspectos Peculiares que Caracterizam a Feira Livre da Cidade de Corumbá-MS.Disponível em: http://www.admpg.com.br/2013/down.php?id=288\&q=1 (consultado em setembro 2018).

Saquet, M. A. (2011). Por uma geografia das territorialidades e das temporalidades: uma concep̧̧ão multidimensional voltada para a cooperação e para o desenvolvimento territorial. São Paulo: Outras.

Saquet, M. A. (2013). Abordagens e concep̧̧óes sobre território (3). São Paulo: Outras Expressões.

Sato, L. (2007). Processos cotidianos de organização do trabalho na feira livre. Revista Psicologia \& Sociedade. 9(8), 95-102.

Santos, J. E. (Org.) (2009). O Desenvolvimento Econômico da Feira Livre de Umbaúba, 1989 a 2009. Disponível em: http://www.revistas.unipar.br/index.php/veterinaria/article/download/4939/2878 (consultado em setembro 2017).

Santos, R. C. O, Oliveira, M. A. M. (2012). Trabalhadores Bolivianos em Feiras Livres na Cidade de Corumbá, MS. (Relatório Final PIBIC do projeto de Iniciação Científica do CNPq 2011/2012). Corumbá, MS. Universidade Federal de Mato Grosso do Sul, Campus do Pantanal, Brasil.

Schneider, S. (2003). Teoria Social, Agricultura Familiar e Pluriatividade. Revista Brasileira de Ciências Sociais, 18(51), 99-122. 
Silva, C. B. (2003). Economia Informal em Corumbá/MS: A chamada "Feirinha Boliviana" e pequenos comerciantes ambulantes - realidade e cotidiano (Monografia de graduação), Universidade Federal de Mato Grosso do Sul, Corumbá, MS, Brasil.

Souza, S. L. (2010). As Hortaliças de Origens Boliviana Ofertadas nas Feiras Livres de Corumbá: Aspectos Transfronteiriços (Dissertação de Mestrado), Universidade Federal de Mato Grosso do Sul, Corumbá, MS, Brasil.

Telles, V. S. (2010). A cidade nas fronteiras do legal e ilegal. Belo Horizonte: Argvmentvm.

\section{Notas}

1 Os dados referidos as Leis e Decretos datados na década de 1950 / 1960 foram obtidos a partir da pesquisa documental, conforme destacada na estratégia de pesquisa nos acervos da Câmara dos Vereadores de Corumbá.

2 Feira Bras-Bol é um antigo centro comercial de Corumbá formado por brasileiros e bolivianos que comercializavam roupas, calçados e acessórios, cosméticos, artigos para lar e outros. Era quase que o camelódromo da cidade.

3 No item "outros" são representados por mais de 10 produtos diferentes, que incluem desde brinquedos, peças para eletrodomésticos, CDS e DVS, bijuterias, artigos de perfumaria, ferragens, peças para bicicletas, aviamentos, artesanatos, acessórios para celular, eletrônicos, ervas medicinais, entre outros. Optou-se nesse caso por unir esses tipos de produtos que individualmente teriam menor representativa do que as categorias individualizadas

4 Portunhol ou portanhol é uma palavra-valise que designa a interlíngua (ou língua de confluência) originada a partir da mistura de palavras da língua portuguesa e da espanhola. Ocorre, sobretudo, em cidades de fronteira entre países de língua portuguesa e espanhola (Faulstich, 1997). 